Article

\title{
An Optimal Strategic Business Model for Small Businesses Using Online Platforms
}

\author{
Hana Kim ${ }^{1}$, Daeho Lee ${ }^{2}$ and Min Ho Ryu ${ }^{3, *(D)}$ \\ 1 Technology Management, Economics and Policy Program, Seoul National University, 1 Gwanak-ro, \\ Gwanak-gu, Seoul 08826, Korea; tea112@snu.ac.kr \\ 2 Department of Interaction Science, Sungkyunkwan University, 25-2 Sungkyunwan-ro, Jongno-gu, \\ Seoul 03063, Korea; daeho.lee@skku.edu \\ 3 Graduate School of Management of Technology, Hoseo University, Asan 31499, Korea \\ * Correspondence: ryumh12@gmail.com; Tel.: +82-010-2736-6716
}

Received: 11 February 2018; Accepted: 23 February 2018; Published: 26 February 2018

\begin{abstract}
As ecommerce continues to grow, small businesses are using a variety of platforms to secure potential consumers. However, it is important for small business owners to choose an efficient business model because of constraints such as technical problems. In this study, based on platform characteristics we divide online shopping platforms into different types as follows: (1) information brokerage services; (2) online malls; and (3) omni-channel platforms. The efficiency of each group is measured by stochastic frontier analysis, and the efficiency comparison between the groups is made using meta-frontier analysis. As a result of the study, it is found that the efficiency of small business owners increases as functional integration increases, satisfying utilitarian motivations. However, a platform with greater integration that has a social presence satisfying hedonic motivations improves the efficiency of all small businesses using the platform instead of just the efficiency of a marginal number of small business owners. This study, based on the dynamic capabilities viewpoint, suggests that the omni-channel platform represents the most sustainable approach for small business owners undergoing difficulties such as technological and organizational changes.
\end{abstract}

Keywords: strategies for small businesses; online marketplace; technical efficiency; online shopping platforms

\section{Introduction}

With the development of information and communication technology, the channels through which offline sellers can sell their products to consumers are becoming more and more diverse [1]. Many offline sellers are trying to enter the ecommerce market through 'online stores', which sellers construct easily at a low cost in order to advertise and sell products through the web. According to eMarketer [2], online sales are expected to reach 23 trillion US dollars by 2020. However, as the size of the ecommerce market continues to grow, the opportunities for sellers to expose their online stores to consumers are steadily declining. Thus, seller strategies use platforms that entice potential buyers by including their online stores in several platforms that have already secured potential buyers for sustainable profit (e.g., see [3-7]).

Strategically, it is important for small business owners to be present in online platforms, thus securing consumers to satisfy customer needs. Online consumer shopping is related to utilitarian and hedonic motivations [8,9]. Consumer benefits are influenced by efficiency from the rational and purposeful utilitarian motivational points of view, and hedonic motivation refers to consumers' emotions when shopping [10]. Many studies suggest that online shopping attracts consumers through convenience, information availability, customization [11], trust [12], and time efficiency [13] as well as through product diversity $[14,15]$ as elements of utilitarian motivation. On the other hand, 
hedonic motivation includes factors such as socializing and trend discovery [16-20]. There are several types of ecommerce platforms trying to satisfy these customers' needs, and hence it is better for small business owners to use these platforms. However, small business owners cannot use all platforms because of a shortage of resources to manage. Moreover, if a company uses a platform without understanding consumer needs, it may fail [21]. Thus, even though it is true that firms can achieve competitive performance by adopting strategies which adapt disruptive innovation [22,23], and especially by using surrounding sources [24], it is difficult for the small business owners to decide which platform enables them to be competitive and sustainable. That is why small business owners need to choose platforms strategically from a dynamic capabilities point of view.

The simplest form of ecommerce platform is the 'information brokerage' service. According to Timmers (1998), an information broker is an information service provider that adds value to the enormous amount of data on the Internet [25]. Price comparison sites such as Trivago are archetypal information brokerage service providers, as these platforms allow buyers to search individual online stores. Sellers that are not well known can be exposed to more buyers without any intervention on the part of the platform [26,27]. However, profit depends on the buyer's brand preference or loyalty [28,29], so there is a possibility that the increase in a business' net profit will not be sufficient compared to the fee for joining the platform for unknown sellers.

Another representative type of ecommerce platform is the 'online mall'. The online mall is an aggregation of online stores that enhances the transaction function by offering a common framework such as store structure or payment [25]. For a small business with a low reputation and trust, inducing buyers is easier using an online mall such as Amazon because the online mall already has the established the buyer's trust [30]. Also, buyers seek familiarity and convenience with their previous interactions and experiences [31,32], and they want to purchase through a mediator because they trust it due to its reputation [33]. Thus, a small business can reap the benefits of inducing buyers easily by following the online mall's frame. However, there is a drawback in that sellers using an online mall pay larger fees than when using information brokerage services.

In addition, the omni-channel strategy, which integrates online and offline stores, has received great attention recently. Unlike previous studies insisting that eliminating offline stores is better for cost reduction, there is a rising claim that using the link between online and offline stores increases the buyer's satisfaction and therefore the profit [34-40]. There are various studies about channel management on the seller side, such as those on omni-channel management (e.g., see [3-7]). When buyers experience an offline shop as they shop online, there is an increase in their satisfaction [34,35]. Therefore, an online store linked to an offline store can be more attractive to buyers, providing a social presence $[41,42]$ that an online-only store cannot provide.

However, it is true that small businesses with little capital are struggling to enter the online market because of difficulties such as technology obstacles and organization change [43-45], even though sellers go the extra mile by diversifying channels as well as strategies to cope with the development and evolution of ecommerce. Managing several channels requires much higher costs as well as extra effort compared to managing one channel [43-46], so it is paramount for small business owners who do not have sufficient capital and employees to choose the most efficient business model. Therefore, this study measures and compares the efficiency of various types of ecommerce platforms and suggests which platform strategy is the best for small business owners to succeed in the ecommerce market. For this purpose, the financial data of small business owners who sell products through the three different types of shopping platforms (information brokerage services (NAVER Shopping), online malls (Store Farm), and omni-channel platforms (Shopping Window)), is collected from the number one Korean search engine NAVER. Then, the small businesses' efficiencies in terms of those three platforms are measured and compared. Stochastic frontier analysis (SFA) is used to measure the effectiveness of the seller on each platform, and the efficiency of the three groups of sellers is compared through meta-frontier analysis (MFA). To measure efficiency, survey data on personnel expenses, other expenditures, capital stock, and net sales in 2016 is analyzed. 
The second section of this study explains the SFA and MFA methodologies. In the results section, the overall results of the efficiency analysis are presented. In the last section, the conclusions and implications of this study are discussed.

\section{Materials and Methods}

In this study, to elucidate the efficiencies of small business owners in different types of platforms, we first derive the efficiency of the three groups through SFA methodology and then use MFA methodology to compare the efficiencies of small business owners under different production functions.

\subsection{SFA (Stochastic Frontier Analysis)}

SFA estimates technological efficiency using the frontier production function, which represents the relationship between input and output factors as a production function and represents the maximum output relative to input. Technical efficiency (TE) shows the relative technology level of a given firm's actual production compared to the frontier production function. The further away the technological level of the company is from the frontier production function, the less efficient the company is.

In this study, we use the SFA model in Equation (1) based on Battesse and Coelli (1992) to measure the efficiency change over time [47].

$$
Y_{i t}=f\left(x_{i t}, \beta\right) e^{V_{i t}-U_{i t}}, \mathrm{i}=1,2, \ldots, N, t=1,2, \ldots, T
$$

where $Y_{i t}$ is the output of firm $i$ at time $t, x_{i t}$ is an input vector of firm $i$ at time $t, f$ is the production function, $\beta$ is the parameter of the production function, $V_{i t}$ is independent of $U_{i t}$ and is a random error following a distribution of $\mathrm{N}\left(0, \sigma_{v}^{2}\right)$, and $U_{i t}$ is a non-negative random variable indicating the TE of firm $i$ at time $t$. If $V_{i t}$ is a typical random error in a regression, $U_{i t}$ represents the firm's inefficiency. To be sure it is always inefficient, $U_{i t}$ is not negative, and in this paper it is assumed that $U_{i t}$ follows a half-normal distribution.

From Equation (1), $T E_{i t}$, the TE of firm $i$ at time $t$ is given by Equation (2):

$$
T E_{i t}=e^{-U_{i t}}=\frac{Y_{i t}}{f\left(X_{i t}, \beta\right) e^{V_{i t}}}, i=1,2, \ldots, N, t=1,2, \ldots, T
$$

In general, the Cobb-Douglas and translog functions are the most widely used production functions of SFA, but in the case of Cobb-Douglas, there is a tendency to oversimplify by considering the output variable as a linear combination of the input variables only. Therefore, we use the translog function in this study. In particular, assuming a random effects time-varying production model and assuming a production function of the translog form, Equation (1) can be expressed as follows in Equation (3).

$$
\ln Y_{i t}=\beta_{0}+\sum_{m=1}^{3} \beta_{m} \ln x_{m i t}+\sum_{m=1}^{3} \sum_{k \geq m}^{3} \beta_{m k} \ln x_{m i t} \ln x_{k i t}+V_{i t}-U_{i t}
$$

where $x_{1 i t}$ represents the amount of capital $(K)$ at time $t$ of the $i$ th firm, $x_{2 i t}$ represents the amount of $\operatorname{cost}(M)$ at time $t$ of the $i$ th firm, and $x_{3 i t}$ represents the number of employees at time $t$ of the $i$ th firm. In this study, total capital stock is used for $K$, other expenditures are used for $M$, personnel expenses are used for $L$, and net sales are used for output $Y$.

\subsection{Meta-Frontier Analysis (MFA)}

Comparisons of technological efficiencies among groups cannot be performed using traditional SFA because the technical efficiency of a particular company is difficult to compare with that of others operating with other technologies. Therefore, we use a meta-frontier production function that involves the production function of all groups to compare the efficiency levels of other groups operating under different technical conditions [48]. MFA, which in the past has been mainly applied to the agriculture 
industry, has recently been applied to the information and communication technology (ICT) industry (e.g., see [49-54]). In both Na et al. (2017) [53] and this study, the specific industry is divided into three groups based on strategic characteristics and the efficiency of each group is compared using MFA.

The meta-frontier production function model from Battese et al. (2004) is defined as follows [54].

$$
\begin{gathered}
Y_{i t}^{*}=f\left(x_{i t}, \beta^{*}\right)=e^{x_{i t} \beta^{*}}, i=1,2, \ldots, N, N=\sum_{i=1}^{R} N_{j}, t=1,2, \ldots, T, \\
\text { s.t. } x_{i t} \beta^{*} \geq x_{i t} \beta_{(j)} \text { for all } j=1,2, \ldots, T
\end{gathered}
$$

where $j$ is each group and refers to the omni-channel platform $(j=1)$, online mall $(j=2)$, and information brokerage service $(j=3)$. $\beta^{*}$ is the unknown variable vector of the meta-frontier function satisfying Equation (5). From Equation (4) above, the graph of the meta-frontier production function is located above the graph of the production frontier function of each group for all periods. That is, the meta-frontier production function is an envelope of the frontier function of each group based on the same technology. To simplify, we assume the function $f$ in Equation (1) to be $e^{X_{i t} \beta_{(j)}}$, and then Equation (1) can be transformed as follows:

$$
Y_{i t}=e^{-U_{i t(j)}} \times \frac{e^{x_{i t} \beta_{(j)}}}{e^{x_{i t} \beta^{*}}} \times e^{x_{i t} \beta^{*}+V_{i t}(j)}
$$

If we divide both sides of Equation (5) by $e^{x_{i t} \beta^{*}+V_{i t(j)}}$, it becomes Equation (6):

$$
\frac{Y_{i t}}{e^{x_{i t} \beta^{*}+V_{i t(j)}}}=e^{-U_{i t(j)}} \times \frac{e^{x_{i t} \beta_{(j)}}}{e^{x_{i t} \beta^{*}}}
$$

In Equation (6) shown above, the first part of the right side is the TE of group $j$, and the second part is the ratio of the $j$ group frontier production function to the meta-frontier production function, which is expressed as either the technical gap ratio (TGR) or the meta-technology ratio (MTR). The TE*, representing the technical efficiency of the meta-frontier function, is expressed as the product of TE and TGR, and can be expressed as follows.

$$
T E_{i t}^{*}=\frac{Y_{i t}}{e^{x_{i t} \beta^{*}+V_{i t}(j)}}=T E_{i t} \times T G R_{i t}
$$

Linear programming (LP) is a method of measuring the parameters of the meta-frontier function, and it minimizes the sum of the absolute values of the deviations. According to Battese et al. (2002), LP is defined as follows [54].

$$
L P: \min _{\beta^{*}} L^{*}=\sum_{t=1}^{T} \sum_{i=1}^{N}\left|x_{i t} \beta^{*}-x_{i t} \hat{\beta}_{(j)}\right|, x_{i t} \beta^{*} \geq x_{i t} \hat{\beta}_{(j)}
$$

\section{Data and Results}

\subsection{Data}

In order to measure efficiency, this study collects data through a survey on small business owners registered as sellers in NAVER in 2016. In order to increase the objectivity of the questionnaire response, we first ask questions in a multiple choice form with ranges as the responses and then ask for the actual amount. The number of surveyed companies in each group is shown in Table 1. Among the 345 shopping companies, those with missing data and those with no employees are excluded. 
Table 1. The number of small business respondents.

\begin{tabular}{ccc}
\hline Type of Platform & The Number of Respondents & The Number of Validated Respondents \\
\hline NAVER Shopping & 72 & 56 \\
Store Farm & 74 & 59 \\
Shopping Window & 199 & 153 \\
Total & 345 & 268 \\
\hline
\end{tabular}

For input, monthly average personnel expenses, monthly average other expenditures excluding personnel expenses, and capital stock are used, and the monthly average net sales value is used as the output variable. A total of 268 shopping companies, which can be estimated without omission, are classified according to whether each is an information brokerage service (NAVER Shopping), online mall (Store Farm), or omni-channel platform (Shopping Window), which is an offline-online collaboration platform. The basic statistics of each group are shown in Table 2.

Table 2. Basic statistics for each group (number of firms: 268).

\begin{tabular}{cccc}
\hline & \multicolumn{3}{c}{ Type of Platform } \\
\cline { 2 - 4 } & Omni-Channel Platform & Online Mall & $\begin{array}{c}\text { Information } \\
\text { Brokerage Service }\end{array}$ \\
\hline Number of small businesses & 153 & 59 & 56 \\
\hline Average net sales & $25,664.706$ & $219,447.119$ & $39,341.071$ \\
(thousand KRW) & $(34,445.805)$ & $(738,098.315)$ & $(116,408.607)$ \\
\hline Average personnel expenses & 2646.667 & 8406.780 & 7453.571 \\
(thousand KRW) & $(2280.568)$ & $(14,909.206)$ & $(27,457.241)$ \\
\hline Average other expenditures & 7236.275 & $11,315.254$ & 4917.857 \\
(thousand KRW) & $(10,921.834)$ & $(22,648.168)$ & $(10,827.736)$ \\
\hline Average capital stock & $29,861.373$ & $75,474.576$ & $24,621.429$ \\
(thousand KRW) & $(54,090.892)$ & $(271,062.150)$ & $(28,102.506)$ \\
\hline
\end{tabular}

Note: KRW = South Korean Won. Numbers in parentheses are standard deviations.

\subsection{Efficiency Comparison Results}

In order to analyze the difference in efficiency of small business owners on different platforms, SFA is used to estimate the production functions for all three groups: the omni-channel platform group, online mall group, and information brokerage service group. The efficiency of each group is then measured through the distance from the production function. We then compute the meta-frontier production function that encompasses the estimated production function and compare the efficiency of each group. Table 3 shows the production function of each group estimated by SFA and the result of the meta-frontier production function derived by the LP method through Matlab. 
Table 3. Estimation results of group and meta-frontier production functions.

\begin{tabular}{|c|c|c|c|c|c|c|c|}
\hline & \multicolumn{2}{|c|}{$\begin{array}{l}\text { Omni-Channel } \\
\text { Platform }\end{array}$} & \multicolumn{2}{|c|}{ Online Mall } & \multicolumn{2}{|c|}{$\begin{array}{c}\text { Information Brokerage } \\
\text { Service }\end{array}$} & \multirow{2}{*}{$\begin{array}{c}\text { Meta-Frontier } \\
\text { Linear } \\
\begin{array}{c}\text { Programming } \\
\text { (LP) }\end{array}\end{array}$} \\
\hline & Estimates & $t$-Value & Estimates & $t$-Value & Estimates & $t$-Value & \\
\hline Constant & $5.5117 * *$ & 2.1102 & 0.1198 & 0.0593 & $9.1295^{* * *}$ & 10.3261 & 0.0068 \\
\hline $\ln x_{1}$ & -0.0442 & -0.0678 & -0.8098 & -0.7027 & $-2.1970 * * *$ & -13.5473 & 0.0847 \\
\hline $\ln x_{2}$ & -0.4271 & -0.8388 & $1.8626^{*}$ & 1.7048 & 0.3225 & 0.6402 & 0.7628 \\
\hline $\ln x_{3}$ & 0.4066 & 0.9895 & 0.5223 & 0.6598 & 0.5883 & 0.7863 & 0.9654 \\
\hline$\left(\ln x_{1}\right)^{2}$ & $0.1718^{* *}$ & 2.1990 & $0.4753^{* * *}$ & 2.8057 & 0.0172 & 0.9166 & 0.3315 \\
\hline$\left(\ln x_{2}\right)^{2}$ & $0.1402^{* *}$ & 2.5747 & 0.0531 & 0.4637 & $-0.2112^{* * *}$ & -3.8034 & 0.1579 \\
\hline$\left(\ln x_{3}\right)^{2}$ & 0.0510 * & 1.6826 & 0.1211 & 1.5261 & $0.0788^{* * *}$ & 2.9432 & 0.1818 \\
\hline $\ln x_{1} \times \ln x_{2}$ & -0.0746 & -0.7587 & -0.3299 & -1.4444 & $0.5626^{* * *}$ & 5.8707 & -0.1893 \\
\hline $\ln x_{2} \times \ln x_{3}$ & -0.0919 & -1.6053 & -0.0603 & -0.4322 & $-0.1834^{* * *}$ & -8.4452 & -0.2416 \\
\hline $\ln x_{3} \times \ln x_{1}$ & -0.1035 & -1.1916 & -0.2810 * & -1.8331 & -0.0701 & -1.4387 & -0.2888 \\
\hline
\end{tabular}

Note: * Significant at 0.1 level; ${ }^{* *}$ Significant at 0.05 level; ${ }^{* * *}$ Significant at 0.01 level.

Based on the estimation results in Table 3, the technical efficiency, technical gap ratio (TGR), and meta-frontier efficiency of each group are estimated from the estimated SFA production function and meta-frontier production function of the three groups according to platform characteristics. The results are summarized in Table 4 .

Table 4. Technical efficiencies and meta-technology ratios. TE: technical efficiency of the stochastic frontier; TGR: technical gap ratio; TE*: technical efficiency of the meta-frontier function.

\begin{tabular}{|c|c|c|c|c|}
\hline Group & Mean & SD & Minimum & Maximum \\
\hline \multicolumn{5}{|c|}{$\mathrm{TE}$} \\
\hline Omni-channel platform & 0.5062 & 0.2069 & 0.0200 & 0.8534 \\
\hline Online mall & 0.3555 & 0.1944 & 0.0003 & 0.7597 \\
\hline Information brokerage service & 0.4354 & 0.3279 & 0.0208 & 0.9994 \\
\hline \multicolumn{5}{|c|}{ TGR } \\
\hline Omni-channel platform & 0.4493 & 0.2019 & 0.0041 & 1.0000 \\
\hline Online mall & 0.5353 & 0.2939 & 0.0146 & 1.0000 \\
\hline Information brokerage service & 0.3061 & 0.2324 & 0.0002 & 1.0000 \\
\hline \multicolumn{5}{|c|}{$\mathrm{TE}^{*}$} \\
\hline Omni-channel platform & 0.2231 & 0.1348 & 0.0020 & 0.6648 \\
\hline Online mall & 0.1906 & 0.1622 & 0.0003 & 0.6873 \\
\hline Information brokerage service & 0.1201 & 0.1079 & 0.0002 & 0.3964 \\
\hline
\end{tabular}

In Table 4, the omni-channel platform group has the highest TE $(0.5062)$, followed by the information brokerage service group (0.4354) and online mall group (0.3555). This means that the average efficiency of small businesses using the omni-channel platform is the closest to the group's frontier production function. From the perspective of standard deviation (SD), the SD is usually low when TE is low in many studies, except in the case of online malls (e.g., [50-52]). In the case of online malls, although the efficiency of small business owners in the group is disperse, the deviation is not large (0.1944). That is, the variation of the efficiency distribution is not large. Timmers (1998) stated that the more functionality integration or channel integration the online shopping platform has, the greater the degree of integration [25]. A small business owner who uses an online mall should follow rules such as the store structure and the payment method provided in the online mall. The omni-channel platform is highly integrated because sellers on an omni-channel platform should follow the framework provided by the platform, not just for channel integration, but also for communication with consumers. 
In other words, as the degree of integration increases, the number of rules that sellers have to follow in the platform increases so that the providers provide similar services within the same platform. Thus, the variance of the efficiency distribution of small business owners on the omni-channel platform is not large (0.2069). On the other hand, even though the efficiency of an information brokerage group's production function is closer to its frontier production function than the online mall group, the deviation of the distribution is relatively large (0.3279). This might be because the low-integrity information brokerage service does not provide the seller with a framework, so that if the seller does not manage a technical problem due to the low competence of the seller, the productivity is lowered if the consumer is not satisfied.

However, in the case of SFA, it is meaningless to compare technological efficiency with other groups because it assumes different types of production functions and obtains technical efficiency values under each production function. Thus, different groups can be compared by obtaining the values of TGR or TE* through the meta-frontier production function. As a result, in terms of TGR based on LP, the production function of the online mall with a medium degree of integration is closest to the meta-frontier production function (0.5353), followed by the omni-channel platform and the information brokerage service group (0.3061).

From the perspective of TE* including a group's efficiency compared to other groups and the efficiency of the group itself, the omni-channel platform group shows the highest result (0.2231), which means not only that the retailers' production function in the group is close to the group's frontier function but also that the group production function is close to the meta-frontier production function. Next, the online mall (0.1906) is ranked lower in the TGR rankings in terms of TE*, as the efficiency deviation within the group is larger than for the omni-channel platform. Finally, the TE* value of the information brokerage service group is the lowest (0.1201).

In conclusion, the $\mathrm{TE}^{*}$ of the omni-channel platform group (which has the highest TE value) is the highest, which means that the upward movement of the group's production function to the meta-frontier production function is due to the increase in all small businesses' efficiency, not due to the success of a minute number of small business owners. Still, in terms of TGR, the online mall group, which involves an integrated platform that provides an online sales framework rather than online and offline integration, is closest to the meta-frontier production function because this group shows the highest TGR value. This means that the online mall group's productivity is the highest compared to the other groups.

\section{Discussion}

With the development of the Internet, ecommerce has continued to grow as offline sellers begin to sell products through online stores. With this growth, however, it becomes more difficult to expose the online store itself to consumers, so the sellers are trying to attract buyers to their online stores through a variety of platforms in order to secure potential consumers. However, it is pivotal for small business owners to choose an efficient business model because it is not easy to manage multiple channels due to capital or technical problems. Therefore, in this paper, platforms are categorized into information brokerage services, online malls, or omni-channel platforms based on platform characteristics in order to discover the best business model for small business owners. As a result of measuring the effectiveness of small business owners on each platform by SFA, the omni-channel platform shows the highest average efficiency, followed by information brokerage services and online malls. When comparing the three groups based on MFA, the TGR of the online mall is the highest, followed by the omni-channel platform and the information brokerage service. In terms of the TE* value reflecting both the efficiency of the group compared to other groups and the efficiency within the group, the omni-channel platform has the highest value, followed by online malls and information brokerage services. That is, the higher the integration of the platform, the greater the seller's productivity.

First, increased functional integration of transactions such as order, payment method, etc., indicates that the platform provides an environment that enhances the seller's productivity by 
inducing the consumer's consumption. Based on the consumer's trust in online malls, such as Amazon, the platform provides sellers a trading environment to gain trust from buyers [30-33] so that consumers will purchase even if a small business has not yet gained much of a reputation or trust. On the other hand, information brokerage services, with the lowest integration, represent an inefficient platform for small business owners to use because sellers using this platform have a low efficiency but also see a significant difference in efficiency between sellers.

However, small business owners can reduce their investment risk using an integrated omni-channel platform that even provides a social presence through online and offline convergence. In a study by Lee et al. (2015) analyzing the music streaming service industry providing the same goods, the group with the highest TE value had the lowest $\mathrm{TE}^{*}$ value, which comes from the group comparison [51]. On the other hand, in the case of sellers providing different goods, it can be seen that integration is important because even though the technical efficiency of the small business owner using the omni-channel platform is a little lower than that for online malls, the efficiency gap among the small business owners in the omni-channel platform group is small. It can be said that the sales framework the platform requires of the seller, for example including the use of offline photo provision, and the way of communicating with the consumer provided by the platform, satisfies consumers. In other words, when the platform provides an environment in which consumers can experience similar experiences online to purchasing goods offline, the satisfaction of the online shopping of consumers increases $[34,35]$. Thus, the efficiency difference between the sellers is not so large that the investment risk is reduced when the seller uses the omni-channel platform.

In summary, even if the platform has a lot of potential consumers, the more the platform provides functional integration that is convenient for consumers use based on their trust in the platform, the more the efficiency of small businesses is improved by inducing the consumption of potential consumers. However, if small business owners want a certain level of stable efficiency, the omni-channel platform is a better platform to opt for. This is because a platform with a high degree of integration that satisfies the social presence of consumers enhances the efficiency of all small business owners rather than just improving the efficiency of a minimal number of small businesses using the platform. Therefore, it is an optimal type of platform for reducing the risk of investment.

In conclusion, this study contributes to expanding the dynamic capabilities view with utilitarian and hedonic motivations. Firstly, small business owners can have competitive performance by choosing a platform with the functional integration which meets the utilitarian motivation of consumers. This is because the platform already provides the information technology that is necessary to improve firms' performance [55] by satisfying the utilitarian motivation. Also, this study suggests that social presence, which provides the experience similar to offline shopping, should be considered as a hedonic motivation in addition to factors such as convenience, information availability, trend discovery, and socializing as utilitarian and hedonic motivations in online shopping [11-20]. Beyond social commerce emphasizing communication with other users [56], consumers seek an online shopping experience similar to that offline. In this context, small business owners can reduce the risk of investment by using the online platform providing a social presence satisfying hedonic motivation as well as utilitarian motivation factors. In terms of the dynamic capabilities viewpoint, this study suggests that small business owners use an online mall if they expect high profitability, but argues that using an omni-channel platform implies a reduction in investment risk.

The limitations of this study are that only the small business owners who use the shopping platform of Korea's representative search company are investigated for the analysis. There are many small businesses that sell through other platforms, so it would be meaningful to analyze this information. Despite these limitations, it is noteworthy that the productivity analysis of small business owners in terms of the degree of integration of platforms reveals an efficient business model among the various platforms being developed, through continuous innovation and integration.

Acknowledgments: This work was supported by the Ministry of Education of the Republic of Korea and the National Research Foundation of Korea (NRF-2016S1A3A2924760). 
Author Contributions: Min Ho Ryu and Hana Kim conceived and designed the experiments; Min Ho Ryu performed the experiments; Min Ho Ryu and Hana Kim analyzed the data; Daeho Lee contributed reagents/materials/analysis tools; Hana Kim wrote the paper.

Conflicts of Interest: The authors declare no conflict of interest.

\section{References}

1. Verhoef, P.C.; Kannan, P.K.; Inman, J.J. From multi-channel retailing to omni-channel retailing: Introduction to the special issue on multi-channel retailing. J. Retail. 2015, 91, 174-181. [CrossRef]

2. Emarketer. Worldwide Retail Ecommerce Sales Will Reach $\$ 1.915$ Trillion This Year. Available online: https: / www.emarketer.com/Article/Worldwide-Retail-Ecommerce-Sales-Will-Reach-1915-TrillionThis-Year/1014369 (accessed on 9 February 2018).

3. Neslin, S.A.; Grewal, D.; Leghorn, R.; Shankar, V.; Teerling, M.L.; Thomas, J.S.; Verhoef, P.C. Challenges and opportunities in multichannel customer management. J. Serv. Res. 2006, 9, 95-112. [CrossRef]

4. Verhoef, P.C.; Neslin, S.A.; Vroomen, B. Multichannel customer management: Understanding the research-shopper phenomenon. Int. J. Res. Mark. 2007, 24, 129-148. [CrossRef]

5. Konuş, U.; Neslin, S.A.; Verhoef, P.C. The effect of search channel elimination on purchase incidence, order size and channel choice. Int. J. Res. Mark. 2014, 31, 49-64. [CrossRef]

6. Ailawadi, K.L.; Farris, P.W. Managing Multi-and Omni-Channel Distribution: Metrics and Research Directions. J. Retail. 2017, 93, 120-135. [CrossRef]

7. Brynjolfsson, E.; Hu, Y.J.; Rahman, M. Competing in the age of omnichannel retailing. MIT Sloan Manag. Rev. 2013, 54, 23-29.

8. Batra, R.; Ahtola, O.T. Measuring the hedonic and utilitarian sources of consumer attitudes. Mark. Lett. 1991, 2, 159-170. [CrossRef]

9. Mikalef, P.; Giannakos, M.; Pateli, A. Shopping and word-of-mouth intentions on social media. J. Theor. Appl. Electron. Commer. Res. 2013, 8, 17-34. [CrossRef]

10. Babin, B.J.; Darden, W.R.; Griffin, M. Work and/or fun: Measuring hedonic and utilitarian shopping value. J. Consum. Res. 1994, 20, 644-656. [CrossRef]

11. Ghosh, S. Making business sense of the Internet. Harvard Bus. Rev. 1998, 76, 126-135.

12. Bart, Y.; Shankar, V.; Sultan, F.; Urban, G.L. Are the drivers and role of online trust the same for all web sites and consumers? A large-scale exploratory empirical study. J. Mark. 2015, 69, 133-152. [CrossRef]

13. Morganosky, M.A.; Cude, B.J. Consumer response to online grocery shopping. Int. J. Retail Distrib. Manag. 2000, 28, 17-26. [CrossRef]

14. Alba, J.; Lynch, J.; Weitz, B.; Janiszewski, C.; Lutz, R.; Sawyer, A.; Wood, S. Interactive home shopping: Consumer, retailer, and manufacturer incentives to participate in electronic marketplaces. J. Mark. 1997, 38-53. [CrossRef]

15. Geuens, S.; Coussement, K.; De Bock, K.W. A framework for configuring collaborative filtering-based recommendations derived from purchase data. Eur. J. Oper. Res. 2018, 265, 208-218. [CrossRef]

16. To, P.L.; Liao, C.; Lin, T.H. Shopping motivations on Internet: A study based on utilitarian and hedonic value. Technovation 2007, 27, 774-787. [CrossRef]

17. Wolfinbarger, M.; Gilly, M.C. Shopping online for freedom, control, and fun. Calif. Manag. Rev. 2001, 43, 34-55. [CrossRef]

18. Dawson, S.; Bloch, P.H.; Ridgway, N.M. Shopping motives, emotional states, and retail outcomes. J. Retail. 1990, 66, 408 .

19. Arnold, M.J.; Reynolds, K.E. Hedonic shopping motivations. J. Retail. 2003, 79, 77-95. [CrossRef]

20. Ladhari, R.; Souiden, N.; Dufour, B. The role of emotions in utilitarian service settings: The effects of emotional satisfaction on product perception and behavioral intentions. J. Retail. Consum. Serv. 2017, 34, 10-18. [CrossRef]

21. Kaplan, A.M.; Haenlein, M. Users of the world, unite! The challenges and opportunities of Social Media. Bus. Horiz. 2010, 53, 59-68. [CrossRef]

22. Schilke, O. On the contingent value of dynamic capabilities for competitive advantage: The nonlinear moderating effect of environmental dynamism. Strateg. Manag. J. 2014, 35, 179-203. [CrossRef] 
23. Teece, D.J.; Pisano, G.P.; Shuen, A. Firm Capabilities, Resources, and the Concept of Strategy: Four Paradigms of Strategic Management; University of California at Berkeley, Center for Research in Management, Consortium on Competitiveness \& Cooperation: Berkeley, CA, USA, 1990.

24. Hartmann, J.; Vachon, S. Linking Environmental Management to Environmental Performance: The Interactive Role of Industry Context. Bus. Strateg. Environ. 2017. [CrossRef]

25. Timmers, P. Business models for electronic markets. Electron. Mark. 1998, 8, 3-8. [CrossRef]

26. Baye, M.R.; Morgan, J. Information gatekeepers on the internet and the competitiveness of homogeneous product markets. Am. Econ. Rev. 2001, 91, 454-474. [CrossRef]

27. Edelman, B.; Jaffe, S.; Kominers, S.D. To groupon or not to groupon: The profitability of deep discounts. Mark. Lett. 2016, 27, 39-53. [CrossRef]

28. Kocas, C. Evolution of prices in electronic markets under diffusion of price-comparison shopping. J. Manag. Inf. Syst. 2002, 19, 99-119.

29. Saeed, K.A.; Grover, V.; Hwang, Y. The relationship of e-commerce competence to customer value and firm performance: An empirical investigation. J. Manag. Inf. Syst. 2005, 22, 223-256. [CrossRef]

30. Pavlou, P.A.; Gefen, D. Building effective online marketplaces with institution-based trust. Inf. Syst. Res. 2004, 15, 37-59. [CrossRef]

31. Van Bruggen, G.H.; Antia, K.D.; Jap, S.D.; Reinartz, W.J.; Pallas, F. Managing marketing channel multiplicity. J. Serv. Res. 2010, 13, 331-340. [CrossRef]

32. Gefen, D. E-commerce: The role of familiarity and trust. Omega 2000, 28, 725-737. [CrossRef]

33. Jarvenpaa, S.L.; Tractinsky, N.; Saarinen, L. Consumer trust in an internet store: A cross-cultural validation. J. Comput. Mediat. Commun. 1999, 5. [CrossRef]

34. Argo, J.J.; Dahl, D.W.; Manchanda, R.V. The influence of a mere social presence in a retail context. J. Consum. Res. 2005, 32, 207-212. [CrossRef]

35. Hassanein, K.; Head, M. Manipulating perceived social presence through the web interface and its impact on attitude towards online shopping. Int. J. Hum. Comput. Stud. 2007, 65, 689-708. [CrossRef]

36. Avery, J.; Steenburgh, T.J.; Deighton, J.; Caravella, M. Adding bricks to clicks: Predicting the patterns of cross-channel elasticities over time. J. Mark. 2012, 76, 96-111. [CrossRef]

37. Bell, D.R.; Gallino, S.; Moreno, A. Offline Showrooms and Customer Migration in Omni-Channel Retail. Demand and Operational Benefits. 2015. Available online: https://www.scholars.northwestern. edu/en/publications / offline-showrooms-and-customer-migration-in-omni-channel-retail (accessed on 11 February 2018).

38. Chu, S.Y.C.; Wu, C.M.; Wu, K.I.F.; Chen, Y.F. Does Established Offline Store Drive Online Purchase Intention? Int. J. Bus. Inf. 2017, 11, 432.

39. Pauwels, K.; Neslin, S.A. Building with bricks and mortar: The revenue impact of opening physical stores in a multichannel environment. J. Retail. 2015, 91, 182-197. [CrossRef]

40. Wang, K.; Goldfarb, A. Can offline stores drive online sales? J. Mark. Res. 2016, 54, 706-719. [CrossRef]

41. Short, J.; Williams, E.; Christie, B. The Social Psychology of Telecommunications; Wiley: Hoboken, NJ, USA, 1976.

42. Rice, R.E.; Case, D. Electronic message systems in the university: A description of use and utility. J. Commun. 1983, 33, 131-152. [CrossRef]

43. Lewis, J.; Whysall, P.; Foster, C. Drivers and technology-related obstacles in moving to multichannel retailing. Int. J. Electron. Commer. 2014, 18, 43-68. [CrossRef]

44. Staflund, L.; Kersmark, M. Omni-Channel Retailing: Blurring the Lines between Online and Offline. Master's Thesis, Jönköping University, Jönköping, Sweden, 25 June 2015.

45. Quader, M.S. The strategic implication of electronic commerce for small and medium sized enterprises. J. Serv. Res. 2007, 7, 25.

46. Ariguzo, G.C.; Mallach, E.G.; White, D.S. The first decade of e-commerce. Int. J. Bus. Inf. Syst. 2006, 1, 239-255. [CrossRef]

47. Battese, G.E.; Coelli, T.J. Frontier production functions, technical efficiency and panel data: With application to paddy farmers in India. J. Prod. Anal. 1992, 3, 149-165. [CrossRef]

48. Battesse, G.E.; Rao, D.S.P. Technology gap, efficiency, and a stochastic metafrontier function. Int. J. Bus. Econ. 2002, 1, 87-93.

49. Yang, A.; Lee, D.; Hwang, J.; Shin, J. The influence of regulations on the efficiency of telecommunications operators: A meta-frontier analysis. Telecommun. Policy 2013, 37, 1071-1082. [CrossRef] 
50. Hong, A.; Lee, D.; Hwang, J. Metafrontier production function analysis of horizontal and vertical integration in Korea's cable TV industry. J. Media Econ. 2011, 24, 221-236. [CrossRef]

51. Lee, C.; Lee, D.; Hwang, J. Platform openness and the productivity of content providers: A meta-frontier analysis. Telecommun. Policy 2015, 39, 553-562. [CrossRef]

52. Lee, K.; Park, Y.; Lee, D. Effect of the ICT ecosystem structure on the sustainable growth of ICT firms: A metafrontier analysis on China, South Korea, the United States, and Japan. Sustainability 2016, 8, 469. [CrossRef]

53. Na, H.S.; Hwang, J.; Hong, J.Y.J.; Lee, D. Efficiency comparison of digital content providers with different pricing strategies. Telemat. Inform. 2017, 34, 657-663. [CrossRef]

54. Battesse, G.E.; Rao, D.S.P.; O'Donnell, C.J. A metafrontier production function for estimation of technical efficiencies and technology gaps for firms operating under different technologies. J. Prod. Anal. 2004, 21, 91-103. [CrossRef]

55. Mikalef, P.; Pateli, A.G.; van de Wetering, R. It Flexibility and Competitive Performance: The Mediating Role of IT-Enabled Dynamic Capabilities. In Proceedings of the European Conference on Information Systems (ECIS), Sariyer, Turkey, 12-15 June 2016.

56. Huang, Z.; Benyoucef, M. From e-commerce to social commerce: A close look at design features. Electron. Commer. Res. Appl. 2013, 12, 246-259. [CrossRef]

(C) 2018 by the authors. Licensee MDPI, Basel, Switzerland. This article is an open access article distributed under the terms and conditions of the Creative Commons Attribution (CC BY) license (http:// creativecommons.org/licenses/by/4.0/). 